\title{
The Nature of Litigation in Early New England
}

\author{
Claire Priest ${ }^{\dagger}$
}

If Bruce Mann had written Neighbors and Strangers as he describes it in his reply, ${ }^{1}$ he might have been right in stating that I mischaracterized his work. But instead his reply presents a version of legal change revised to write out the central aspects of his theory that I critiqued in my Article. ${ }^{2}$ I used the term "modernization theory" as a simple way of referring to the underlying thrust of Neighbors and Strangers that, in the early eighteenth century, the legal system in colonial Connecticut transformed in response to an expanding economy and other changing social conditions by becoming more formal and predictable and by providing more uniform decisions, thereby creating conditions for a more commercial and market-oriented society. ${ }^{3}$ In one passage, for example, Mann states:

An expanding economy requires that individual transactions be governed by generally applicable rules. Because of the sheer number of such transactions and the distances they may involve, they have to be conducted in a routine fashion. Their form and the legal rules that direct them must be uniform and calculable. Rational economic exchange requires the assurance that like cases will be treated alike. To provide that assurance, general rules override the individuality of particular cases and force them into a common mold. Formal requirements that limit litigation to the instruments themselves and restrict appeals homogenize the

$\dagger$ Law Clerk, Hon. Jon O. Newman, U.S. Court of Appeals for the Second Circuit; Assistant Professor, Northwestern University School of Law.

1. Bruce H. Mann, Correspondence, Law, Economy, and Society in Early New England, 111 YALE L.J. 1869 (2002).

2. Claire Priest, Currency Policies and Legal Development in Colonial New England, 110 YALE L.J. 1303 (2001).

3. I might have simply adopted the language of Comelia Dayton's book review in which she describes Neighbors and Strangers as "a sustained argument for the emergence by 1750 of a legal system geared to serve the interests of a commercial (or capitalist) political economy." Cornelia Dayton, Law and Disputing in Commercializing Early America, 87 MICH. L. REV. 1538, 1546 (1989) (book review). 
underlying transactions and give them a uniform, predictable legal character. $^{4}$

This passage and others like it ${ }^{5}$ portray law and economy as functioning in a tight, mutually reinforcing, and evolving relationship in a context of economic expansion. In the passages of my Article that Mann characterizes as reducing his argument to the claim that "judges, acting instrumentally to promote economic growth, engineered the legal changes," 6 my intention was to show that Mann focuses on local sources of law-on the "law" emerging endogenously out of relationships between individuals within local communities - through resolution of disputes in the courts by judges.

My Article presents a starkly different view of eighteenth-century law by emphasizing the ways in which currency policies enacted by colonial assemblies, mercantilist policies adopted by Parliament and the Board of Trade in England, as well as domestic and international economic conditions influenced the forms in which people transacted and the volume of litigation. Far from the picture Mann presents of increasing calculability accompanying economic expansion, my study shows an economy rocketing between currency gluts and shortages compelling resort to commodity money and barter, with litigation volume careening in response.

More particularly, my focus is the importance of the colonial governments' issuance of the first paper monies to an understanding of debt litigation during the first half of the eighteenth century in New England. In my account, the issuance of paper money, in a society largely operating without coins or other cash, had the potential to lead to greater commercialization, specialization, and less household subsistence, but these ambitions were not realized because of unstable government currency policies. Each colony's annual determination of the paper currency in circulation reflected a struggle within colonial assemblies, which faced pressure from part of the public - often debtors- to issue paper money in greater volume, and conflicting pressure from English and New England merchants who desired a stable currency of high value to satisfy English import debts. The tensions between the elected representative assemblies

4. BRUCE H. MANN, NEIGHBORS AND STRANGERS: LAW AND COMMUNITY IN EARLY CONNECTICUT 36 (1987).

5. E.g., id. at 31 ("[T]he agrarian economy of Connecticut grew enough to change the contours of commercial activity."); id. at 37 ("The formal rationality of written instruments made them better suited than book accounts to credit transactions in the expanding economy of eighteenth-century Connecticut."); id. at 41 ("The expansion of the economy in the eighteenth century did not mean that all commercial dealings had become faceless and impersonal.... [P]opulation growth, migration, and economic development drew people beyond town and county boundaries and changed the way they did business with one another."); $i d$. at 44 ("[F]ormally rational credit instruments facilitated the establishment of routine credit transactions in an expanding economy.").

6. Mann, supra note 1, at 1871. 
and the English-representatives of a foreign sovereign promoting a mercantilist agenda-led to policies that created disastrous uncertainty. New England experienced periods of extreme depreciation and periods of currency scarcity in the years 1726 to 1730,1733 to 1734 , and 1738 to 1741 , when colonial citizens were forced to revert to barter and commodity money exchange.

I present data revealing that the periods of greatest currency instability coincide with periods of exponentially increasing litigation. Moreover, contemporary pamphlets concerning Massachusetts's currency policies show that colonial citizens were frustrated by the swamping of the courts with debt-related litigation during periods of currency instability, that some complained bitterly about excessive court fees, and that serious questions were raised about judges' dogged enforcement of the common-law principle of nominalism-allowing debtors to satisfy their debts with payment in nominal, not real, values of the debts. Thomas Hutchinson (the future governor), for example, wrote in 1736: “[T]he Government is the Guarantee that all just \& legal Contracts shall be perform'd; but with us they are daily broken, \& necessarily will be so, whilst our Money continues in its present fluctuating Circumstances." 7

Mann views our depictions of law in New England in the eighteenth century as compatible (actually, he asserts that I present a new strand of his interpretation). I disagree. Mann refers to economic advance in connection with legal development so many times in Neighbors and Strangers that it is impossible to characterize my Article-uniformly finding that New England colonial growth rates were low and litigation rates volatile-as consistent with his analysis. ${ }^{8}$ Mann concedes the low rate of economic growth in his reply, but there remains a fundamental conflict between our accounts. The conflict at base involves the question of whether debt litigation ending in default or confession of judgment represented colonial

7. A LeTter to a MEMBER OF THE HONOURABle HOUSE OF REPRESENTATTVES, ON THE PRESENT STATE OF THE BILLS OF CREDIT (Boston, 1736), reprinted in 3 COLONIAL CURRENCY REPRINTS, 1682-1751, at 150, 160-61 (Andrew McFarland Davis ed., 1910). I found strong ties among currency policies, debt litigation, and the seeds of revolution in Massachusetts. During a period of severe currency scarcity (and high levels of debt litigation), there emerged a widespread popular movement to establish a private bank backed by land. Parliament suppressed the Land Bank by applying the Bubble Act to the colonies in 1740. John Adams later claimed that the "act to destroy the Land Bank scheme raised a greater ferment in this province than the Stamp Act did." JOHN ADAMS, NOVANGLUS; OR, A HISTORY OF THE DISPUTE WITH AMERICA, FROM ITS ORIGIN, IN 1754, TO THE PRESENT TIME (1774), reprinted in 4 THE WORKS OF JOHN ADAMS 3, 49 (Charles Francis Adams ed., Boston, Charles C. Little \& James Brown 1851) (emphasis added).

8. A recent article by Peter C. Mancall and Thomas Weiss proposes that the rate of colonial economic growth was most likely close to zero, see Peter C. Mancall \& Thomas Weiss, Was Economic Growth Likely in Colonial British North America?, 59 J. ECON. Hist. 17 (1999), a lower estimate than those proposed by the economic historians cited in my Article, Priest, supra note 2 , at 1340 n. 126 
creditors using litigation as a mechanism for securing credit (Mann's characterization, on which he bases his theory of legal modernization) or, rather, whether those judgments primarily represented real defaults deriving from deep economic instability (my characterization).

A central empirical finding presented in Neighbors and Strangers is that when colonial citizens began relying with greater frequency on formal, written credit instruments, litigation in the vast majority of cases ended in either confession of judgment or default. Mann notes the absence of contestation of this debt litigation (particularly in comparison to litigation on book accounts, where debtors contested debts at higher rates) and concludes that the certainty of formal credit instruments led to a system whereby "credit had become something extended in single transactions in return for formal admissions of liability." In Mann's account, colonial litigation served as a form of securing credit, much like filing a financing statement under the Uniform Commercial Code. Mann infers from this interpretation that more confessions of liability and more default judgments, generally speaking, suggest greater commercialization, particularly when economic advance is assumed. Thus Mann states:

Commercial expansion brought with it-indeed, rode the crest ofa rising tide of indebtedness. ... The sharp increase in uncontested debt actions in the $1730 \mathrm{~s}$, in particular the sudden tendency of debtors to confess judgment against themselves to facilitate collection by their creditors should they fail to repay, underscored not only the massive increase in indebtedness but also the acceptance of indebtedness as a necessary cost of doing business. ${ }^{10}$

In my account, confessions of judgment and defaults were not a rationalized means of security recordation, but represented creditors using litigation to collect debts after real defaults during fluctuating economic conditions. Contemporary sources indicate that the defaults were of two sorts. During periods of currency depreciation, debtors failed to repay their debts as a delaying tactic to benefit from declining currency values, forcing their creditors to sue. ${ }^{11}$ In contrast, during periods of monetary scarcity,

9. MANN, supra note 4 , at 40 .

10. Id. at 62 .

11. In a 1743 pamphlet, one writer claimed:

This [legal tender] Law ... habituat[ed] Debtors to suffer themselves to be sued for indisputable Debts, and to appeal from Judgments obtain'd against 'em upon their own Defaults to the Superior Court merely for Delay; ... this Sort of Actions multiply'd in Proportion, to the great Hurt and Scandal of the Country; insomuch that the Number of such Suits within the Province was increas'd... Between the Years 1730 and 1742, to near double what it was before.

AN ENQUIRY INTO THE STATE OF THE BILls OF CREDIT OF THE PROVINCE OF MASSACHUSETTSBAY IN NEW-ENGLAND IN A LETTER FROM a GENTLEMAN IN BOSTON TO A MERCHANT IN 
often coinciding with economic recessions, litigation followed widespread default. ${ }^{12}$

Mann's interpretation of litigation, that "debtors conceded liability before payment for their creditors' convenience," 13 assumes a key empirical fact: that litigation occurred close in time to the execution of the debt agreement. The ambition of debt recordation is to establish a legal priority to a debtor's assets. Delay of any period reduces the value of the debt by affording an opportunity for other creditors to establish claims prior or equivalent to the previously extended debt. Mann recognizes the importance of this empirical fact. Indeed, in his reply, Mann urges an empirical study of this question to resolve whether his interpretation or mine is right. ${ }^{14}$

Unfortunately, Mann appears to have missed my Note in The Yale Law Journal, where I present the results of exactly the empirical study he proposes. ${ }^{15}$ Using the records of the Plymouth County Courts, I examined over 3500 cases ending in a default judgment in the period 1724 to 1750 to determine the length of time between the date the parties entered debt agreements and the date creditors filed suit to collect. Mann's interpretation implies that litigation to enforce debts was brought at the time the credit agreements were entered into or shortly thereafter. My interpretation-that confessed judgments and defaults in the first half of the eighteenth century primarily represented real defaults-implies an interval between debt execution and litigation beyond the term of the debt. The customary terms of credit extended to local retailers in the period ranged from six to twelve months, though sometimes less. ${ }^{16}$

I found that the median interval between debt execution and litigation for all debt litigation ending in default between 1724 and 1750 was 531.5 days (17.5 months). ${ }^{17}$ Only $14.5 \%$ of all debt cases resulting in default were litigated within six months of the execution of the debt agreement. ${ }^{18}$ I

LONDON (n.p. 1743), reprinted in 4 COLONIAL CURRENCY REPRINTS, 1682-1751, supra note 7, at 149, 162-63 (1911) (citation omitted).

12. As I discuss in two separate places in my Article, both Mann and Dayton note that in 1740 , the year of the highest volume of debt litigation in Connecticut, agricultural prices dropped, which brought debtors to courts in high numbers. Priest, supra note 2, at 1308-09 n.11, 1385-86. Indeed, Mann refers to the 1740 s as a "decade of economic distress" that resulted in abnormally high litigation volumes. MANN, supra note 4, at 62-66. Mann's account of these changes, however, reflects only a variation from the general emphasis on an increase in litigation volume paralleling an expanding economy.

13. MaNN, supra note 4 , at 45.

14. Mann, supra note 1, at 1879.

15. Claire Priest, Note, Colonial Courts and Secured Credit: Early American Commercial Litigation and Shays' Rebellion, 108 YALE L.J. 2413 (1999).

16. See id. at $2431 \&$ n. 70 .

17. See id. at $2436 \mathrm{tbl} .3$.

18. Id. 
therefore concluded that the vast majority of default judgments-at least $85.5 \%$-represented litigation after real defaults.

Mann describes litigation ending in "confessions of judgment" as a more certain example of debt-recording than litigation ending in default. ${ }^{19}$ In Plymouth County from 1724 to 1750 , however, the median interval between the date of the agreement and the lawsuit in cases ending in confession of judgment was over four years (1549.5 days) ${ }^{20}$ In Massachusetts, therefore, confession of judgment did not represent a concession of liability before the creditor planned to collect the debt. It was likely a way to reduce court fees during litigation after a real default. ${ }^{21}$

Notwithstanding our deep differences, I am very grateful to Mann for suggesting ways in which the analysis might be improved. Perhaps I should have given greater recognition to Mann's discussion of paper currency's positive impact on commercialization, although in overlooking the details, he failed to see the true relevance of currency policies to his theory of legal change. Mann's suggestion that the data be adjusted for population growth is complicated. Aggregate population is not the appropriate denominator; the population of debtors or the number of loans might be better, though these metrics, too, are endogenously affected by economic fluctuations. Finally, I could have been clearer that Mann does not focus solely on litigation volume. Changes in litigation over time are so central to his account, however, that my treatment can hardly be regarded as unfair. Indeed, he again emphasizes his "confession of liability" theory - which, unfortunately, the Massachusetts data do not support-as a further argument in his reply.22

Unfortunately, Professor Mann has read my Article too personally. There are many significant contributions in his highly detailed book, and it

19. See Mann, supra note 1, at $1878 \mathrm{n} .46$ ("Confessions of judgment clearly constitute an admission of liability.").

20. Priest, supra note 15 , at 2438 tbl.4.

21. My Note proposes that high court fees prevented creditors from using the courts for recordation purposes. I analyzed court fees in relation to the value of underlying debts. In a 1740 court session, for example, I found that, for the lowest quartile of debts (debts in the smallest amounts), court fees represented $79 \%$ of the value of the underlying debt. Id. at 2426 tbl.1. On average, court fees represented $32.6 \%$ of the underlying debt. Id. I compared fees to estimates for wages at the time and found that court fees represented on average eight days of work for a farmer, 5.8 days of work for a skilled craftsman, and almost two weeks of work for a seaman. Id. at 2427 tbl.2. I concluded that litigation purely to record debts was an undesirable strategy; indeed, burdening debtors with court fees may have decreased creditors' chances of repayment. The Massachusetts government did not provide for an inexpensive means of recording debts until after Shays' Rebellion. See An Act for Rendering Processes in Law Less Expensive, ch. 43, 17861787 Mass. Acts 105; Priest, supra note 15, at 2447.

22. Mann, supra note 1, at 1878-79; see also CORNELIA HUGHES DAYTON, WOMEN BEFORE THE BAR: GENDER, LAW, AND SOCIETY IN CONNECTICUT, 1639-1789, at 90, 102 (1995) ("In essence, the burgeoning volume of uncontested debt cases represented the capitalization of the New England economy."). 
contains many important insights that my Article does not address. ${ }^{23}$ Regrettably, however, like much other legal history, Mann's work only touches upon, but does not take seriously, the problems of money supply in the colonies, although they were intimately related to litigation in the period he describes. As a consequence, his account of legal development remains misdirected. A fuller history of the nuanced relations among law, economy, and society must necessarily place currency policies more centrally in the account.

23. Mann accuses me of unfairly criticizing Dayton. Mann, supra note 1 , at 1872 n.17. I thought it so obvious that my Article does not address the core contributions of Dayton's Women Before the Bar-a classic account of the role of women in the colonial courts-that I did not think it necessary to distinguish the focus of my Article at great length. I cannot imagine any legal scholar believing that I have "tarred" Dayton. 
HeinOnline -- 111 Yale L.J. 1888 2001-2002 


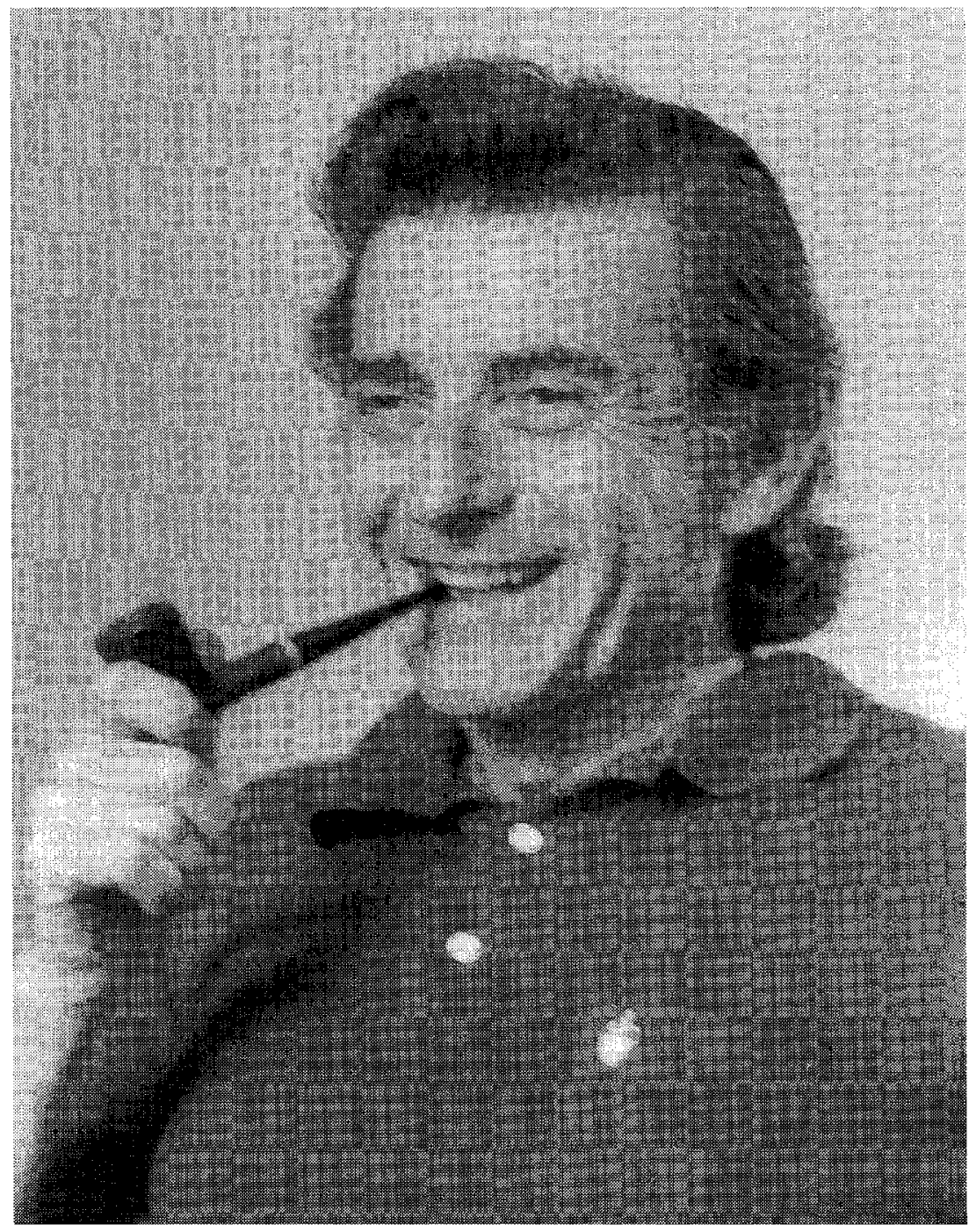

Charles L. Black, Jr.

HeinOnline -- 111 Yale L.J. [i] 2001-2002

Imaged with the Permission of Yale Law Journal 
HeinOnline -- 111 Yale L.J. [ii] 2001-2002 Imaged with the Permission of Yale Law Journal 